\title{
生体応用に向けた傾斜機能材料の作製と特性
}

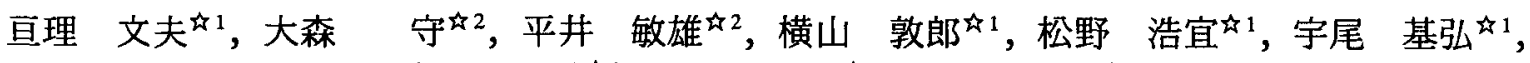 \\ 宮尾 里香 ${ }^{41}$, 田村 豊的，川崎 貴生的1

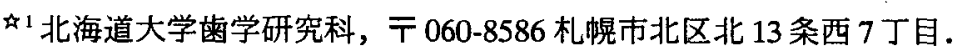 \\ 2 2 東北大学金属材料研究所, $\overline{9} 980-8577$ 仙台市青葉区片平 2-1-1.
}

\section{Fabrication and Properties of FGM for Biomedical Application}

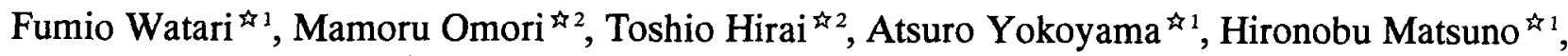 \\ Motohiro Uo ${ }^{\text {1 }}$, Rika Miyako ${ }^{\text {1 }}$, Yutaka Tamura ${ }^{\text {1 } 1}$ and Takao Kawasaki 11 \\ ${ }^{4}$ Graduate School of Dental Medicine, Hokkaido University, Kita 13, Nishi 7, Kita-ku, Sapporo 060-8586. \\ ${ }^{42}$ Institute for Materials Research, Tohoku University, 2-1-1 Katahira Aoba-ku, Sendai 980-8577.
}

Received July 31, 2000

\begin{abstract}
SYNOPSIS
Functionally graded implants composed of titanium (Ti) and hydroxyapatite (HAP) were fabricated by powder metallurgy to satisfy both mechanical properties and biocompatibilities. Concentration gradience was formed either by sedimentation in solvent liquid or by packing dry powders into mould, followed by compressing and sintering. Electric furnace heating, high frequency induction heating and spark plasma sintering (SPS) methods were used for sintering. SPS could make the stable functionally graded materials (FGM) with the gradual change of concentration in the longitudinal direction from pure Ti to 100\%HAP (Ti/100HAP). Animal implantation tests were done to evaluate biocompatibility in soft tissue and osteogenesis in hard tissue. Histological observation by optical microscopy using the thinly sectioned, stained specimens and elemental mapping by EPMA and XSAM (X-ray scanning analytical microscope) using the unstained block specimens showed that the tissue reacted gradiently in response to the graded composition of FGM implant. This implies the possibility to control the tissue response through the gradient function of FGM.
\end{abstract}

KEY WORDS

FGM, biomaterial, titanium, hydroxyapatite, biocompatibility

\section{1 高齢社会と機能性生体材料}

科学・医学の進歩, 経済の進展により豊かな暮らしと長寿 命を享受する時代にあるが, 一方, 出生率の低下と高跲者の 人口比率の増加から, 年齡分布は逆ピラミッド型になり, 若 年層への負担は増大している.こうした中, 高粭者には長寿 を享受するとともにできるだけ自立し充実した老後を送るこ とか，個人の幸福の観点からも，健全な社会福祉財政の観点 からも求められている. 生体材料には病気や疾患からの回復 に寄与するだけでなく，予防や健康增進にも比重を置いた機 能性が求められる.また蔵器移植が盛んになりつつあるが, 倫理性, 数量的限界や機能性の進歩の可能性の点から極力, 人工藏器で代用する方向に向かうだるう. かくして生体・歯 科材料の重要性はますます高まると考えられ，今後ともその 開発は不可欠である.

生体材料は多様な特性を総合的に満足するために, 複合材 料であることが多いが，とりわけ異種成分からなる構造をコ
ントロールし，医学・歯学・生物学的機能の最適実現を図る ために傾斜機能材料の概念”は魅力的であり応用は多数考え られる.しかし異種材料を同一条件下で処理するため，その 作製は必ずしも容易ではない．また材料の傾斜性に対する生 体反応性の変化も確認する必要がある.本稿ではチタンIハイ ドロキシアパタイト (T/HAP) 系を中心に進めてきた傾斜機能型 インプラントの試作例およびその生体反応性に関する基礎的 研究結果 ${ }^{2-7)}$ について述べる.

\section{2 生体材料に求められる特性}

Fig.1は生体材料に求められる特性を歯科材料 ${ }^{8-10)}$ の例で示 したものである．使用される環境はさまざまで，手術を受け た顎骨を固定接合するチタンプレートは生体内に全体が埋入 されるインプラント(人工骨)であり,クラウンや義菌床など の歯科補緅物は生体外の 1 種とも言える口腔内で使用され， デンタルンプラント(人工雪根)は体内から体外へ貫通する 
構造を有している。そそれそれれ要求される程度は異なるが, 耐 食性. ${ }^{11}$, 反応性などの化学的特性, 生体親和性, 骨親和性 ${ }^{12)}$ などの生物学的特性を満足するとともに疲労強度, クリープ 強度, 耐摩耗性, 破壊勒性などの機械的特性, 熱膨張率, 熱 伝導率, 寸法精度などの物理的特性，さらに審美性，操作性， 経済性等を総合的に満足せねばならない，必然的には各種材 料を組み合わせたさまざまな構造の複合材料が多く用いられ ることになる。

軟組織が自然治瘜能力を有するのに対し，骨や歯の硬組織 では一度久損すると再生能力がないために人工材料を用いて 再建する．即ち，軟組織の怪我，病気には薬で治療するのに 対し，硬組織に対しては材料で治療するのであり，治療法の 革新的な進歩は新しい材料の導入によって起きるのが常であ る.かっては金属材料の比重が高かったが，近年ではセラ

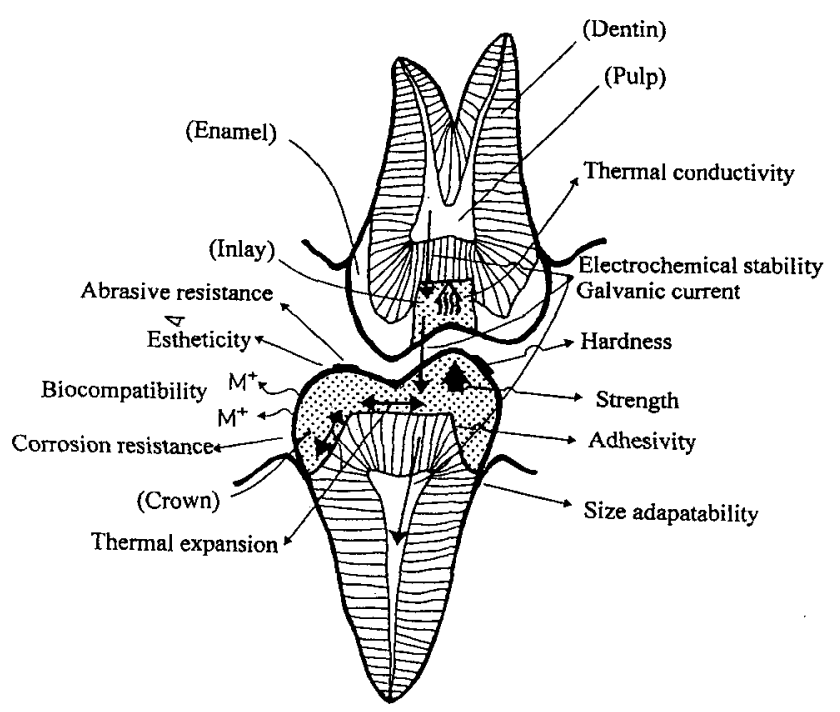

Fig.1 Various properties required for dental materials.

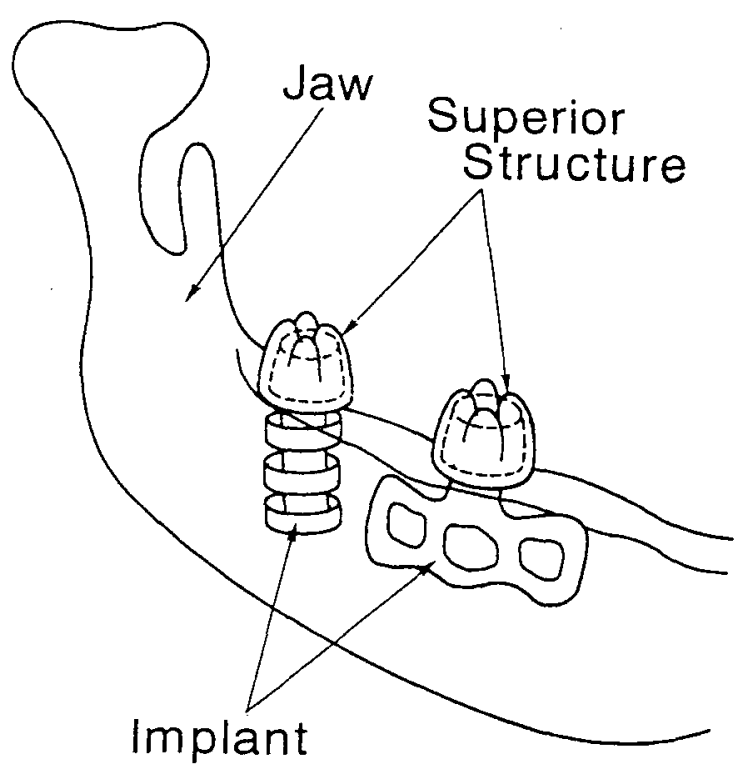

Fig.2 Schematic of a dental implant.
ミックス,ポリマ一の比重が高くなりつつあり, 今後, 生体 漞和性, 予防性, 抗菌性, 薬理作用, 接着性, 審美性などを 付加したより高度な機能性が求められるたろう.

\section{3 人工歯根}

Fig.2に人工歯根の概念模式図を示した. 人工歯根は怪我, 老齢化，その他で歯牙を㻗失した場合に筫骨に植立して，新 生骨の形成により䫑骨内埋入部位が固定されることを期待し， 咬合・咀衡機能を人工的に回復するために顎骨上に露出した 部位は歯冠部に相当する補緅物が適合するように支台型をな している.材料として現在までにアルミナ単結晶, アパタイ 卜焼結体，チタンなどが用いられきた。人エアパタイトはす ぐれた骨親和性を示すが, 破折しやすく，破壊勒性が低い。こ の弱点を改善するために金属の中で最も生体親和性にすぐれ るTi表面にアパタイト ${ }^{13-16)}$ をコーティングすることも行われ ているが,アパタイト層の界面からの剥離，埋入組織中での 吸収消滅が問題となる。

\section{4 傾斜㙨能型インプラント}

人工曾根は骨内から骨外へ貫通する構造のため, 蕷骨内埋 入部, 額骨外(口腔内)およびそれらの境界部は果たすべき機 能と要求される特性が異なっている.しかし現在用いられて いる多くは先端から基底部まで長さ方向に同一構造, 同一材 料で構成されている.

本研究では繰り返し応力が直接負荷されるインプラント上 部に強度特性のすぐれた Tiを, 骨内に埋入される下部には雬 牙主成分のアパタイトを多く配合し，傾斜機能型人工歯根の

\section{F GM ( Functionally}

Gradient Materials)
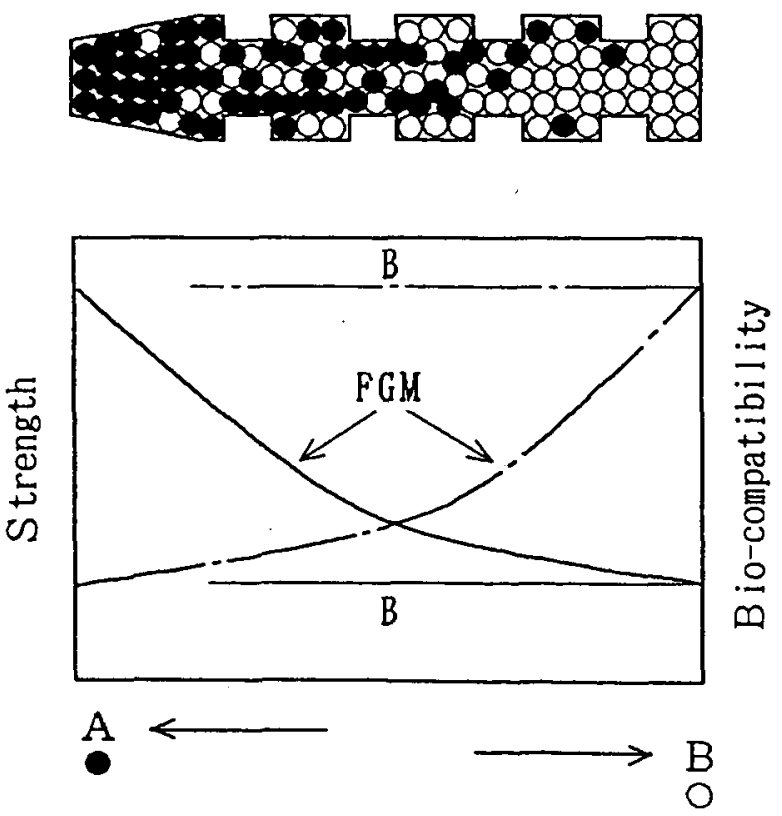

Fig.3 Expected properties of functionally graded dental implant. 
作製を試みた(Fig.3). Ti-アパタイト間を長さ方向に濃度傾斜 させ, 界面形成による物性の断絶を引き起こすことなく連続 的に変化させ, 各部位の機能性を最適に発揮することを意図 した.

一端を純Tiとし, 長さ方向に濃度傾斜し, 他端を HAP 高濃度 含有材 (例えば Ti-20\%HAP) となるような試料を以下, Ti/20HAP のように表記する.

\section{5 濃度傾斜形成}

傾斜機能材料の作製には最もオーソドックスな粉来冶金的 手法を用いた. 沈降法 (Fig.4) または乾燥粉末の逐次充填 (Fig.5) により濃度傾斜を形成し, CIP (冷間静水圧) 加圧成形後, 電 気炉 (Fig.6) または高周波誘導加熱 (Fig.7-9)による焼結，ある

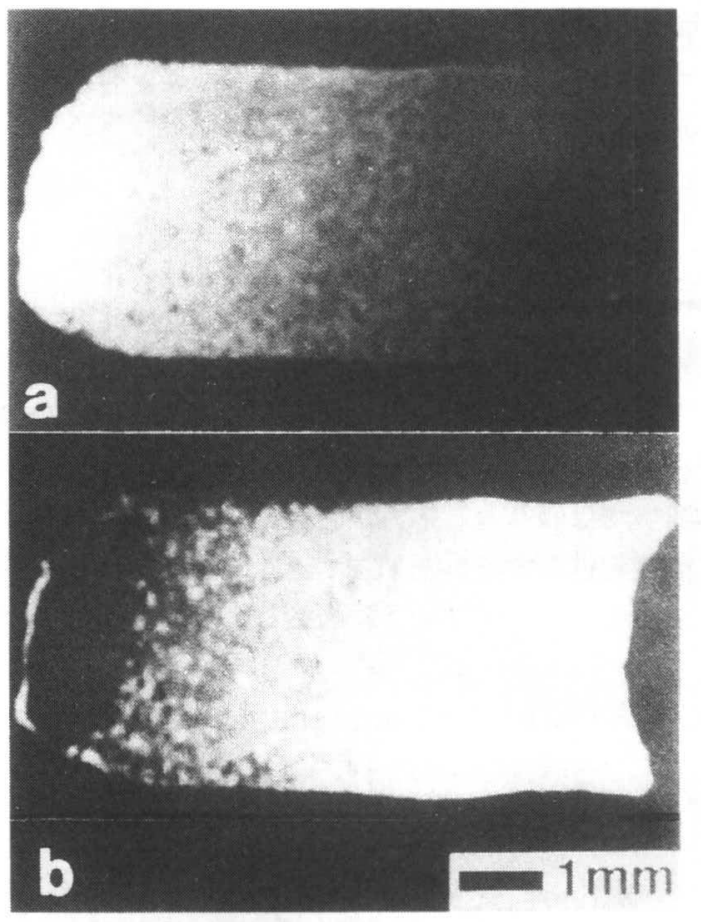

Fig.4 XSAM elemental mapping of Ti/HAP FGM formed by sedimentation method in ethanol. a: $\mathrm{Ti}, \mathrm{b}: \mathrm{Ca}$

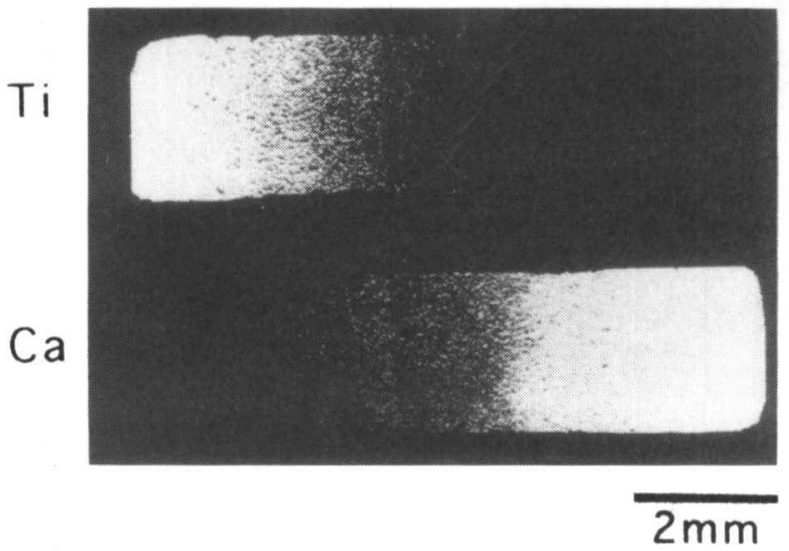

Fig.5 EPMA elemental mapping of Ti and $\mathrm{Ca}$ for Ti/HAP made by packing of dry powder.
いは直接, 放電プラズマ焼結 (SPS) (Fig.10)を行なった.

Fig.4は濃度傾斜形成を沈降法で行い, SPS 法で焼結したTi/ 100HAP 傾斜材である. 実際に濃度傾斜が実現されているか, XSAM (X線走査型分析顕微鏡) ${ }^{17,18)}$ で元素マッピングしたもの で, a は Ti, b は HAP の代表元素としての Ca の分布を表示し ている.

Fig.5は熱収縮チューブへの乾燥粉末の逐次充填により濃度 傾斜形成した Ti/100HAP 傾斜機能型インプラント断面の EPMA 元素マッピング像である. 充填後, CIPで $1000 \mathrm{MPa}$ まで 加圧し, 成型体を $\mathrm{Ar}$ 雾囲気中 $1300^{\circ} \mathrm{C} て ゙$ 電気炉焼結して作製 した.

Fig.4, 5 ともに左側部の純 Ti から, 右に行くほど Ti 濃度は 減少し, 逆にアパタイトを代表する Ca濃度は相補的に増加し 最右部で最強になっている。

\section{6 焼 結 法}

Fig.6は電気炉焼結法で作製した Ti/20HAP 傾斜機能型イン プラント断面のSEM像である. ラットに埋入するためにサイ ズはミニチュア $(1 \phi \times 10 \mathrm{~mm})$ になっている. Fig.6の左外側の 純 Ti部から, アパタイト粒子の含有密度が右方向に増加して いるのが確認される．最右部では Ti-20\%HAPである.

Fig.7は CIP 加圧成形後, 高周波誘導加熱法を用いて焼結し た $4.5 \phi \times 15 \mathrm{~mm}$ の人工歯根型インプラント $(\mathrm{Ti} / 20 \mathrm{HAP})$ の 1 例

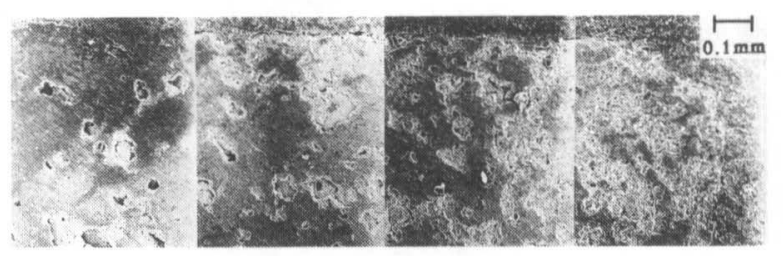

Fig.6 SEM image of the cross section of Ti/20HAP FGM implant around the region biased toward $\mathrm{Ti}-20 \% \mathrm{HAP}$ (right side).

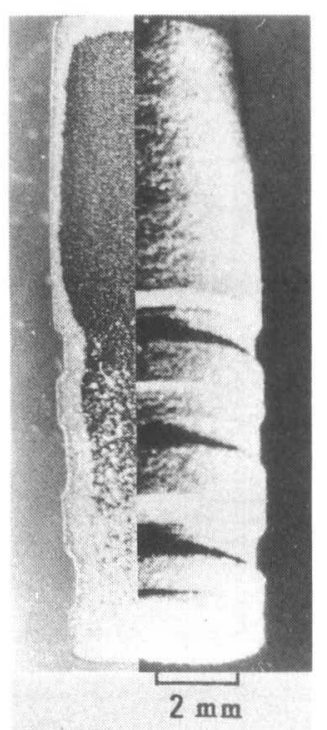

Fig.7 Observation of Ti/20HAP FGM implant, external appearance and cross-section. 
で, 外観と断面像を示す. 口腔内に位置する上方部は機械的 特性を重視し上部約 $1 / 2$ 部分まで純 $\mathrm{Ti}$, 嚬骨内に埋入される下 方部は外形への凹凸の付与とともに，内部では歯や骨の主成 分であるアパタイト濃度を下方向に徐々に増加して最下部で $20 \mathrm{wt} \%$ アパタイト(体積\%は重量\%の約 2 2.5 倍程度)とし, 骨親和性を重視する構造となっている. 試料表面近傍でコン トラストが変化しているのは焼結中の酸素固溶により硬さが 上昇した $\mathrm{Ti}$ 表面硬化層が存在するためである.

Fig.8 は Ti/50HAP 傾斜機能型インプラントを断面内, 長さ 方向にEPMAを用いて線分析を行ったものである. プローブ 径は約 $1 \mu \mathrm{m}$ である. 上方にはほぼ同様な形状と類似した組成 傾斜構造を持つ Ti/20HAP 傾斜機能型インプラント (左側部 : $\mathrm{Ti}$, 右側部 : 20\%HAP) の断面像を参考までに対比させ呈示し た. $\mathrm{Ca}, \mathrm{P}, \mathrm{O}$ はアパタイトの構成元素である. スパイク状の特 性 X 線信号が Ti では信号強度低下を意味する下向きに現れ, 上向きの強度増加として現れる $\mathrm{Ca}, \mathrm{P}, \mathrm{O}$ と対応している. 左 端の純Ti から右方向の 50HAPへ進むに従い, Ti信号の減少と これと相補的な $\mathrm{Ca}, \mathrm{P}, \mathrm{O}$ 信号の増加が明らかで，企図通り濃 度傾斜が実現していることが確認される.

Fig.9は Fig.8の分析に用いた Ti/50HAPインプラントの断面 における各部位を SEM 観察したものである. Fig.9a は Ti5\%HAP 部, b は Ti-40\%HAP 部である. bではアパタイト粒子

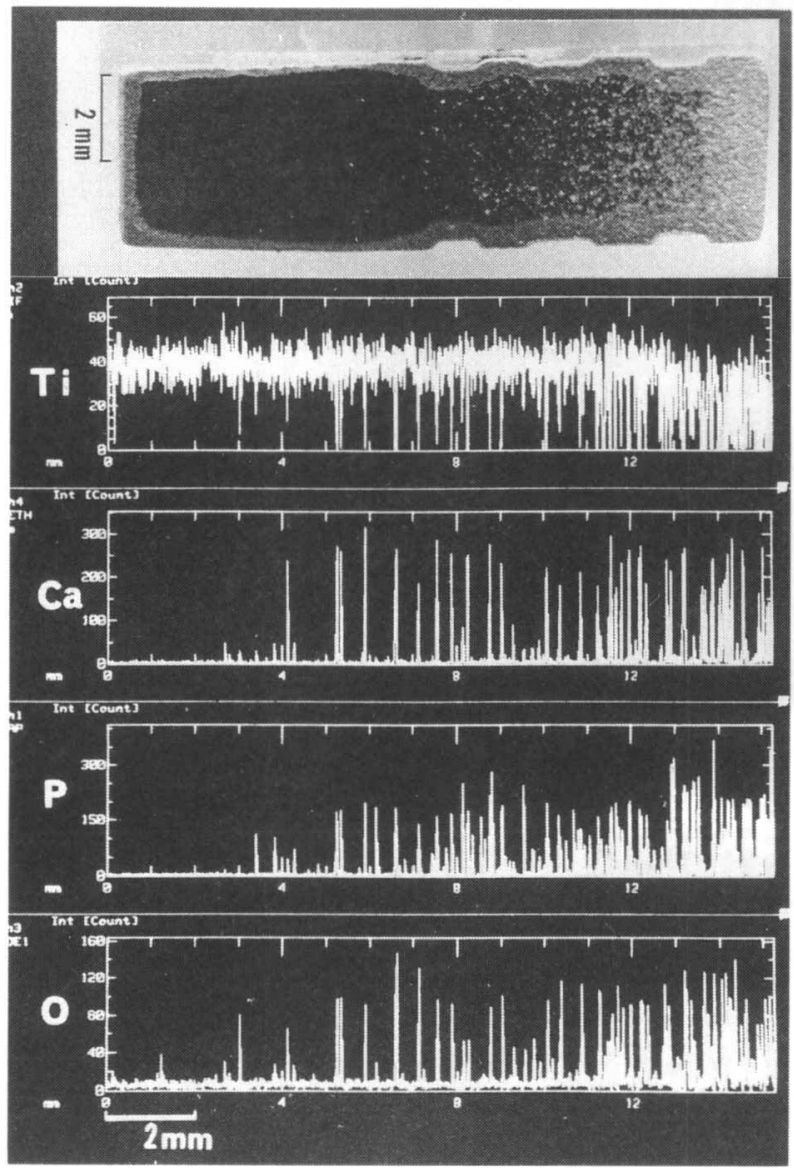

Fig.8 EPMA elemental analysis in the longitudinal direction on the cross-section of Ti/50HAP FGM implant.
は帯電効果のため白色コントラストを示しその分布が良く認 識できる. 気孔率が相当程度高く, Ti とアパタイトの界面に おける接合領域は小さいことから，第一義的には物理的混合 に近い状況にある.

Fig.10は放電プラズマ焼結法で作製したTi/100HAPインプラ ントで，まず高さ方向に濃度傾斜したより大型 $(20 \phi \times 12 \mathrm{~mm})$ の傾斜材を作製し，これから $1 \times 1 \times 12 \mathrm{~mm}$ の角柱状に切り出 したものである. 大型試料は Ti から 100\%HAP まで平均的に 十分良い濃度傾斜を実現していたが, 角状に切り出した後の 本試料ではたまたま大きなHAP粒子が一部混在した個所に当 たり，傾斜性は乱れている.

\section{7 軟組織埋入試験}

生体親和性を評価するには細胞毒性試験から動物実験を経

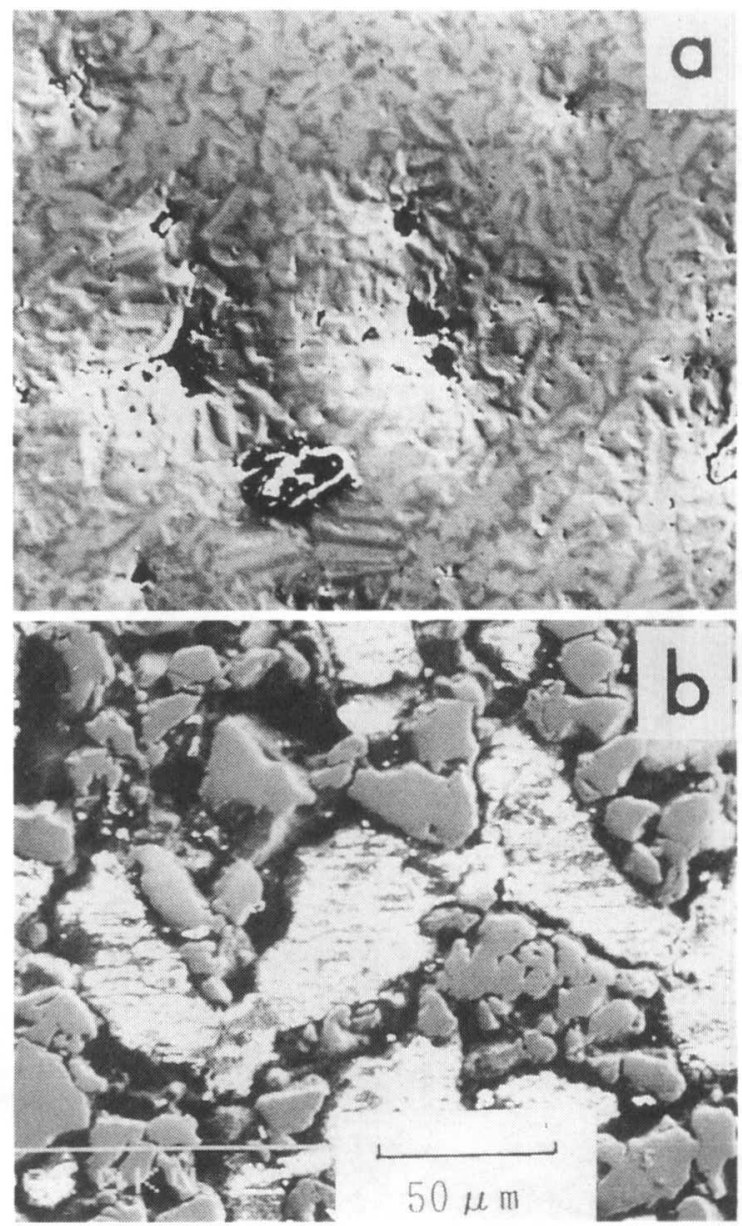

Fig.9 Enlargement of Ti-5HAP (a) and Ti-40HAP (b) regions in Ti/50HAP FGM of Fig.8.

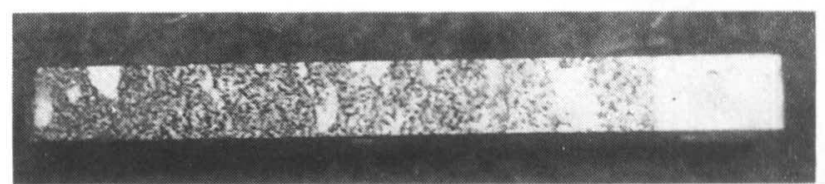

Fig.10 Ti/100HAP FGM made by SPS method (left: Ti, right: 100HAP). 
て臨床試験に至る各段階がある. 人工歯根のサイズは $20 \mathrm{~mm}$ 以下で傾斜機能材料として小型であるが, ラットやウサギに 埋入するためにさらに小さいミニチュア $(2 \phi \times 6 \sim 10 \mathrm{~mm})$ 試験 片を作製し, 動物埋入実験を行った. 皮下への軟組織埋入試 験は主として材料の生体親和性, 生体為害性について, 硬組 織埋入試験は新生骨の形成能について評価することを主たる 目的としている.

Fig.11 は Ni を 2 週埋入したラット軟組織周囲の光学顕微鏡 像 $(\mathrm{OM})$ と X 線分析顕微鏡による Ni マッピング像である. Ni はアレルギーを引き起こす最も代表的な金属であり, その為 害性を示す範囲と $\mathrm{Ni}$ 溶出の範囲の関係を可視化している. 中 央穴部が $\mathrm{Ni}$ 小片が埋入されていた部位である. 光顕像では周 囲組織における炎症, 出血, 壊死が認められ, 強い為害性を 示した. マッピング像にはNiの埋入部周辺への溶出拡散が認 められる. 炎症領域と Niの溶出領域はほぼ一致し, 表面から

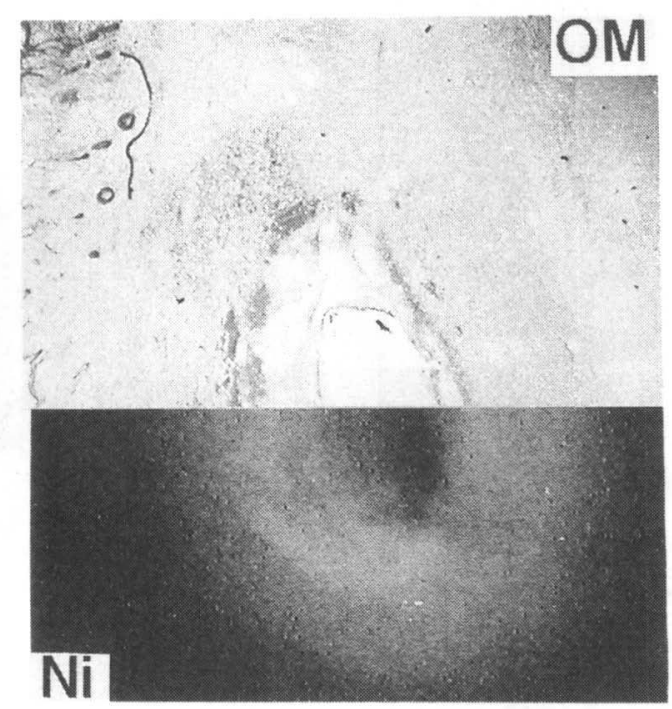

Fig.11 Subcutaneous soft tissue of rat around $\mathrm{Ni}$ after 2 week implantation. Observation by optical microscopy (OM) and Ni mapping by XSAM (Ni).
ほぼ $1.5 \mathrm{~mm}$ の範囲まで及んでおり，このときの濃度は $100-$ $500 \mathrm{ppm}$ のオーダーと推定される.

Fig.12に Ni, Ti, Ni-Ti インプラントをラット皮下に 1 週埋入 後の周囲軟組織を示す. Niでは組織が壊死し, 強い為害作用 を示すが, Ni-Ti, Ti ではインプラントを被包化する線維性結 合組織が形成されており, 生体親和性に富む材料の典型的な 反応である. Ni-Ti では $\mathrm{Ti}$ の不動態皮膜形成による $\mathrm{Ni}$ 溶出の 低減の結果として生体親和性を示したと考えられる. Tiと Ni$\mathrm{Ti}$ への反応は類似しているが, より詳細に見ると細胞核の密 度, 染色濃度は Ni-Ti のほうが Tiよりも高く, 相対的に生体 がより強く反応していることを示している. 純 Tiのほうが長 期的にはより良好な生体親和性を示すと予想される.

Fig.13に親和性に富む Ti とやや劣る Co からなる傾斜材 (Ti/ $100 \mathrm{Co})$ を軟組織に埋入した例を示す. 比較のため行なった純 Tiインプラントでは線維性結合組織の厚さは全体にわたって ほぼ一様な厚さで観察されたのに対し, Ti/Coインプラントで は $\mathrm{Ti}$ 側の健全な組織から Co 濃度が増加するにつれ線維性結

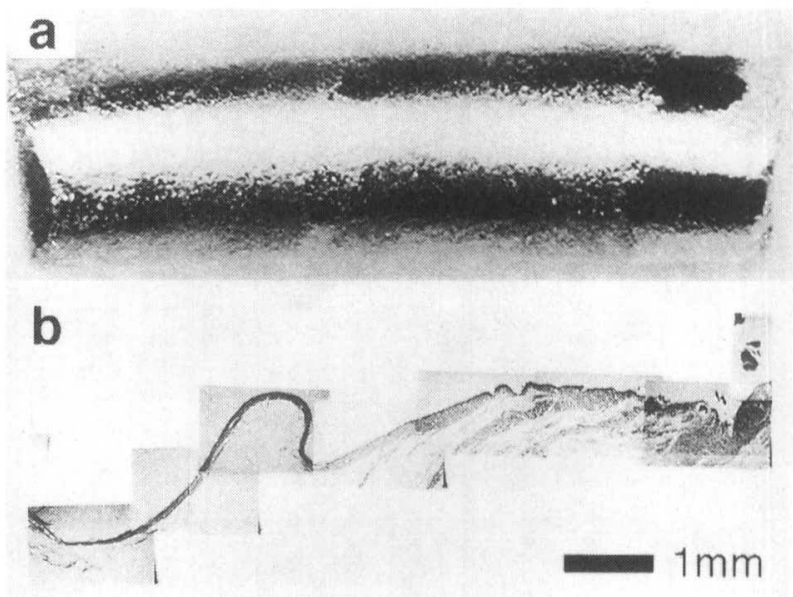

Fig.13 Ti/Co FGM (a) and surrounding tissue reaction after 2 week implantation.

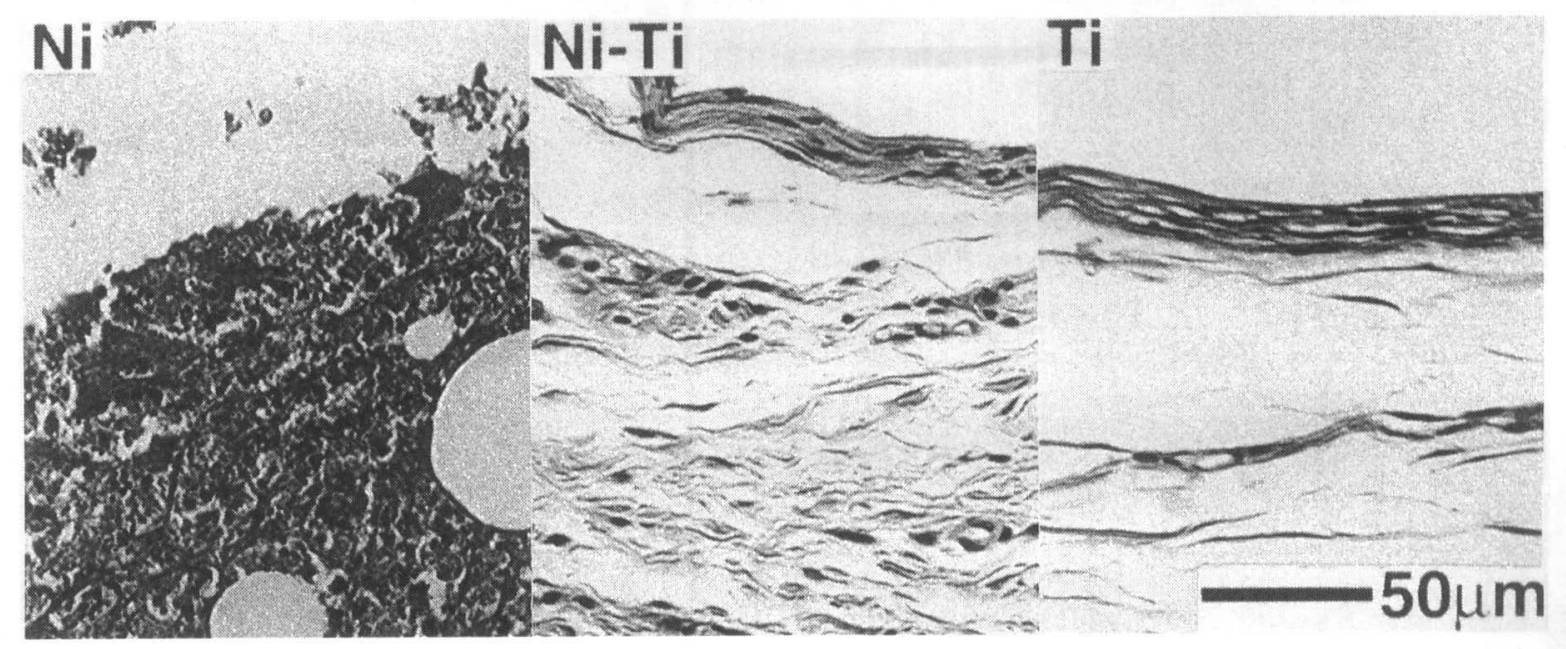

Fig.12 Tissue reaction to $\mathrm{Ni} \mathrm{(a),} \mathrm{Ni-Ti} \mathrm{(b)} \mathrm{and} \mathrm{Ti}$ (c) after 1 week implantation in rat. Fibrous connective tissue was formed around $\mathrm{Ti}$ and $\mathrm{Ni}-$ $\mathrm{Ti}$, while necrosis occurred around $\mathrm{Ni}$. 


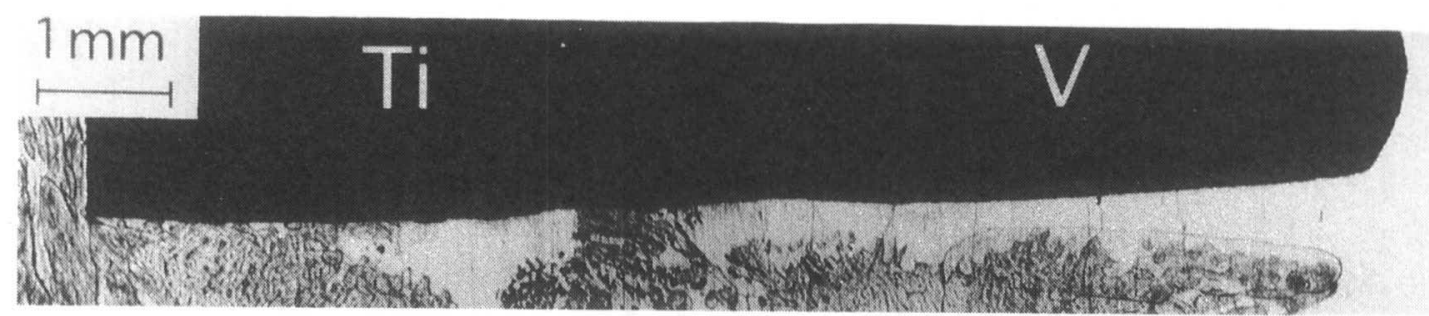

Fig.14 Histological observation of bone formation and resorption around Ti|V biimplant inserted in tibia of rabit for 4 weeks. New bone was formed directly contact to $\mathrm{Ti}$ but cortical bone looked to be absorbed in contacting part to $\mathrm{V}$ and juvenile immature bone was formed with separation from $\mathrm{V}$ implant.

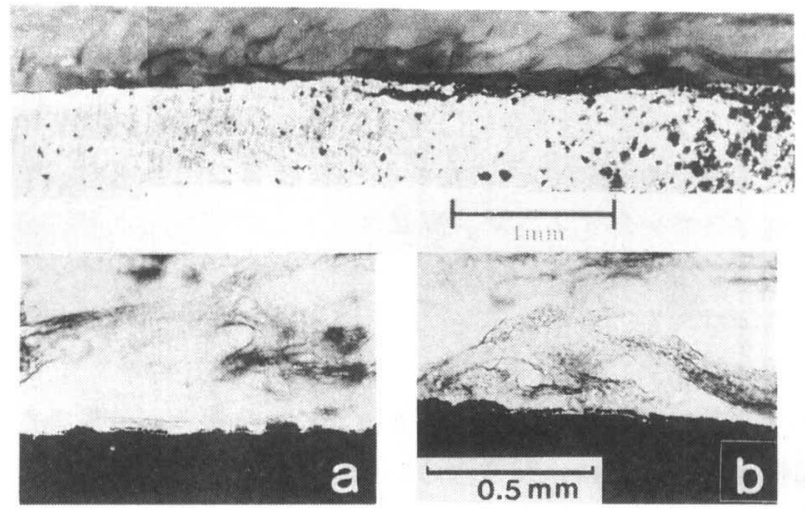

Fig.15 New bone formation around Ti/20HAP FGM implant after 4 week insertion in bone marrow of tibia of rabbit observed by optical microscopy in reflection mode. With the increase of HAP content toward the right new bone observed with black contrast was more formed, directly contact to the implant surface. Enlargement in transmission mode is shown for $\mathrm{Ti}$ (a) and Ti-20HAP (b) regions.

合組織の厚さが大きくなり，かつ炎症性反応が増大し，傾斜 的に生体反応が変化する様子が顕著に観察された. XSAMに よる元素マッピング表示では Ti の溶出は見られず, Co 側で Co 溶出濃度が増加し, 炎症性反応の程度の増加と良い一致を 示した.

\section{8 硬組織埋入試験}

次にインプラントとしての新生骨形成の様子を評価するた めに硬組織埋入実験を行なった. Fig.14はTi とバナジウム(V) を同一条件で比較するために, レーザー溶接で作製した連接 インプラント (左側部: $\mathrm{Ti}$, 右側部: V) を家鬼脛骨に対して垂 直に貫通するように埋入し,4週経過した後の周囲組織像であ る. 本来の皮質骨とその骨䯣腔が中央から左側に円周状に存 在する. 左端の Ti周囲には新生骨が直接接触するように形成 され, 外科手術時の穿孔部が完全に塞がれている.一方, $V$ 側 では新生骨はインプラントと間隔をへだてながら大きく張り 出して成長している. V 側では新生骨が長さ方向の両側に形 成されているが，接触はしておらず，もともとあった皮質骨 の接触部も消失している. Ti の親和性に対し V の為害性が顕 著である。

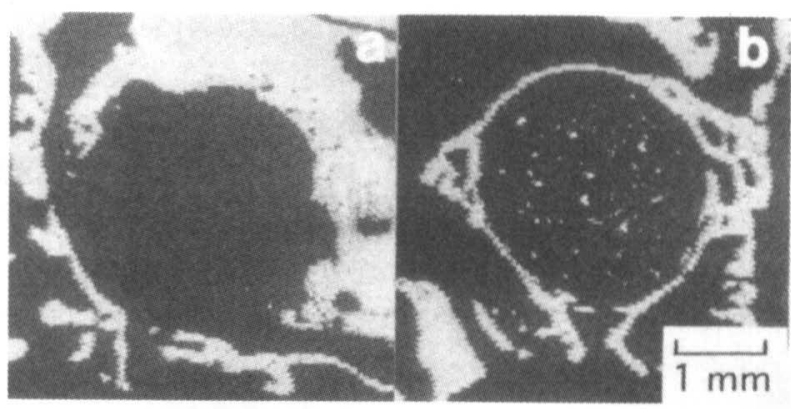

Fig.16 Histological observation of osteogenesis in Ti part (a) and Ti-20HAP part (b) of Ti/20HAP FGM implant after 4 weeks in cavitas medullaris of tibia of rabbit.

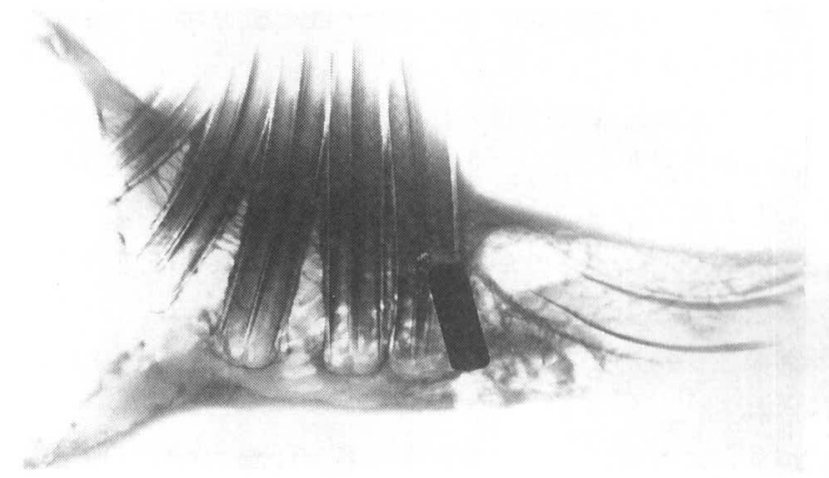

Fig.17 Roentogen image of the implant inserted in the mandible of rabbit.

Fig.15は家鬼脛骨中に 4 週埋入された Ti/20HAP 傾斜材周囲の 新生骨形成を示したもので, Fig.15aは純 Ti 部, bは Ti-20HAP 部近傍の拡大像である. インプラントの Ti HAP 濃度が右方向に増加するのが確認される. また黒いコン トラストで認識される新生骨はインプラント表層に接触する ように形成されており, 左方向の Ti 部 (Fig.15a) から HAP 濃 度が高い右方向(Fig.15b)へ行くほど骨形成量が多いことがわ かる.

Fig.16は $2 \phi \times 6 \mathrm{~mm}$ の Ti/20HAP インプラントを家鬼下顎骨 に8週埋入した後の新生骨形成である.試料は非染色のまま, EPMAのCa マッピング像で観察したもので, a は Ti 近傍, bは Ti/20HAP 近傍である. Fig.17はその埋入状況をレントゲン撮 影したものである.切歯と臼歯の中間下部に埋入されている. 
Fig.16aのTi側では周囲の骨形成量は多いが中央にあるイン プラントからは離れている. bのTi-20HAP近傍ではインプラ ント内部にアパタイトが散在するのが確認される.また新生 骨はインプラント周囲をとりまくように直接接触して形成さ れている.

Fig.15, 16 とも HAP の存在により硬組織中の新生骨が早期 に形成されるのが認められ, 傾斜機能型バイオマテリアルの 構造や機能性の変化に応じ生体が傾斜的に反応する傾向を示 している.

Fig.18は放電プラズマ焼結法を用いて作製した $1 \times 1 \times 12 \mathrm{~mm}$ の Ti/100HAP インプラントをラット大腿骨骨䯣腔内に埋入 2 週後の病理組織像である. 左側が純Ti部, 右側が純HAP部で ある. 上下側は皮質骨であり, 骨髄腔内のインプラント周囲 には新生骨が形成されつつある. Tiも HAPもともに生体親和 性に富む材料であるために部位による大きな違いは顕著では ないが, HAP含有量が高いほど埋入早期からインプラント材 料表面に直接接触するように新生骨形成が進行する傾向が見 られる。

\section{9 結 言}

アパタイト (HAP) は骨や歯質など硬組織の主成分であり, Ti は金属中, 最も生体親和性にすぐれるとされる. Coは生体 親和性がやや劣り, Niはアレルギー性を引き起こす最も典型 的な材料である.

Ti/Co系傾斜材では濃度変化によりインプラント材各部位の 為害性の程度が変化し, それに応じて組織の反応が顕著に変 化した. Ti/HAP 系では HAP 量の増加とともに硬組織中の新 生骨形成が変化するのが認められた. いずれも傾斜機能構造 の導入により生体が傾斜的に反応することを示している．臓 器移植に代わる人工臓器, 徐放性インプラントへの応用も期 待される.

焼結には電気炉, 高周波誘導加熱, 放電プラズマ焼結を用 いた. Ti と HAPはそれぞれ真空・還元性雾囲気, 酸化性雾囲

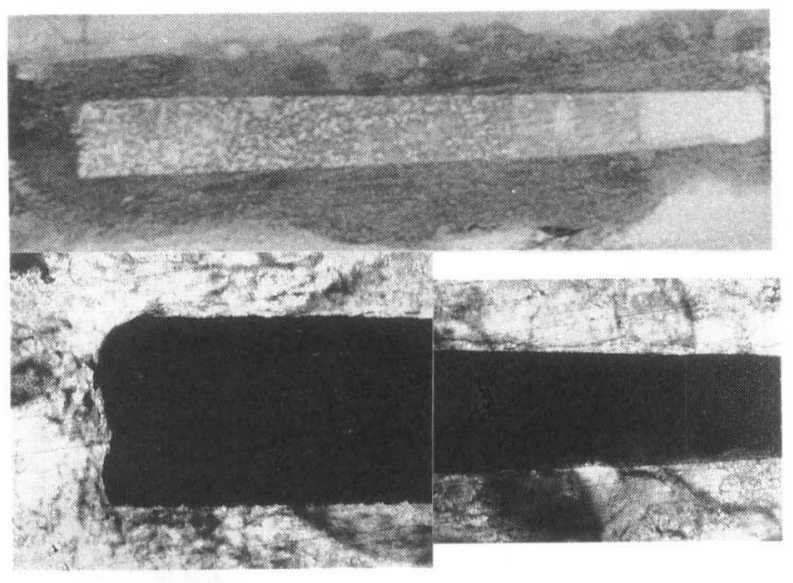

Fig.18 Histological image of Ti/HAP FGM implant inserted in femora of a rat for 2 weeks. Enlargement is shown around the left side of implant (Ti) and the right (HAP).
気で安定であり, 同一条件で焼結するのは困難な組合わせで ある.

電気炉焼結は傍熱方式で試料の外側部から膨張収縮が先行 するので内部応力が発生しやすく, 金属もセラミックス粒子 もともに加熱するので分解作用の低減などの効果は期待しに くい.

高周波誘導加熱は金属粉末の内部から発熱するため, 強固 な酸化皮膜におおわれ粒子間結合が困難な Tiの焼結には効果 があり, 内部応力の発生も小さいと考えられる.またセラ ミックスは発熱しないから, 分解は比較的小さいと期待され るが, 高濃度部は焼結不可能で Ti/HAP系では Ti-30HAP付近 が焼結可能な限界であった.

放電プラズマ焼結(SPS)は粒子間放電による焼結促進, 焼結 温度の低下が期待され, かつ高周波誘導加熱と違い, セラ ミックスも発熱するため, 高濃度部も焼結可能であり, 分解 抑制も期待できる.

異種材料を同一条件下で処理する傾斜機能材料の作製に高 周波誘導加熱, 放電プラズマ焼結法の導入は有効であったが, 特性はまだかならずしも十分ではなく, 今後とも作製条件の 傾斜化等の新しい作製方法の開発, 導入が望まれる.

\section{謝辞}

アパタイト試料の提供に当たり, 住友大阪セメント(㧣新材 料事業部大豆生田氏に厚く御礼申し上げます.

\section{文献}

1) T.Hirai: Functionally Gradient Materials, Materials Science and Technology vol.17B, Processing of Ceramics Part 2, eds. R.W.Cahn, P.Haasen and E.J.Kramer, Verlagsgesellschaft, Weinheim, (1996)293-341.

2) 高橋秀直, 亘理文夫, 西村文夫, 中村英雄: "歯科用傾斜機 能材料の基礎的研究一チタン/アパタイト, チタン/シリ 力傾斜材の作製 - ", 歯科材料・器械, 11(1992)462-468.

3) F.Watari, A.Yokoyama, F.Saso, M.Uo and T.Kawasaki: "Functionally Gradient Dental Implant Composed of Titanium and Hydroxyapatite", Proc. 3rd Int. Symp.Structural \& Functional Gradient Materials, Ed. B.Ilschner, Press. Polytech. Univ. Romand., Lausanne, (1995)703-708.

4) F.Watari, A.Yokoyama, F.Saso, M.Uo and T.Kawasaki: "Fabrication and Properties of Functionally Graded Dental Implant", Composites Part B, 28B(1997)5-11.

5) F.Watari, A.Yokoyama, F.Saso, M.Uo and T.Kawasaki: Functionally Graded Materials 1996, "Elemental mapping of functionally graded dental implant in biocompatibility test", Eds. I.Shiota and Y.Miyamoto, Elsevier, Amsterdam, (1997)749-754.

6) 佐相史徳, 横山敦郎, 亘理文夫, 川崎貴生: "チタン/ハイ ドロキシアパタイト系傾斜機能型インプラントの作製と 生体親和性に関する研究 ", 北海道雬学雑誌, 18(1997)85104. 
7) F.Watari, A.Yokoyama, F.Saso, M.Uo, H.Matsuno and T. Kawasaki: "Biocompatibility of Titanium/hydroxyapatite and Titanium/Cobalt Functionally Graded Implants", Functionally Graded Materials 1998, Ed. W.A.Kayser, Trans Tech Publications, Zurich, (1999)356-361.

8) K.J.Anusavice: PHILLIP's Science of Dental Materials, 10th ed., W.B.Saunders, Philadelphia, (1996)75.

9) R.G.Craig: Restorative Dental Materials, 10th ed., Mosby, St. Louis, (1997)137.

10) 亘理文夫: "歯科材料の表面処理と新顕微鏡観察", 表面技 術,表面技術協会, 48(1997)2-7.

11) F.Watari: "In situ etching observation of human teeth in acid agent by atomic force microscopy", J. Electron Microscopy, 48 (1999)537-544.

12) 松野浩宜, 横山敦郎, 亘理文夫, 宇尾基弘, 川崎貴生: "バ
イオイメージングによるIVa, Va族高融点金属の生体適合 性評価 ", 秤科材料・器械, 18(1999)447-462.

13) F.C.M.Driessens and R.M.H.Verbeeck: Biominerals, CRC Press, Boca Raton, (1990)1.

14) H.Aoki: Science and medical application of hydroxyapatite, Japanese Association of Apatite Science, Tokyo, (1991)1.

15) H.Aoki: Medical applications of hydroxyapatite, Ishiyaku ÉroAmerica, Inc., Tokyo, (1994)1.

16）青木秀希: 驚異の生体物質アパタイト, 医蒾薬出版,(1999)1.

17) M.Uo, F.Watari, A.Yokoyama, H.Matsuno and T.Kawasaki: "Dissolution of nickel and tissue response observed by X-ray analytical microscopy", Biomaterials, 20(1999)747-755.

18）亘理文夫: "「視る」にこたわる一歯科医学研究への各種 顕微鏡の応用展開一", 日本曾科医師会雑誌, 51(1999)11991208. 